\title{
COMBINATORIAL EFFECT OF LEPTIN, TUMOR NECROSIS FACTOR-ALPHA, AND VITAMIN D IN PROGRESSION OF TYPE 2 DIABETES IN KASHMIRI POPULATION
}

\author{
INSHAH DIN ${ }^{1}$, SABHIYA MAJID ${ }^{1 *}$, FOUZIA RASHID ${ }^{2}$, ISHRAT HUSSAIN ${ }^{3}$, RAKESH K KOUL ${ }^{3}$, JASIYA QADIR ${ }^{1}$, \\ RABIA FAROOQ ${ }^{1}$
}

${ }^{1}$ Department of Biochemistry, Government Medical College, Srinagar - 190 010, Jammu \& Kashmir, India. ${ }^{2}$ Department of Clinical Biochemistry, University of Kashmir, Srinagar - 190 010, Jammu \& Kashmir, India. ${ }^{3}$ Department of Medicine, Government Medical College, Srinagar - 190 010, Jammu \& Kashmir, India. Email: zululubaba@gmail.com

\author{
Received: 26 June 2018, Revised And Accepted: 04 August 2018
}

\section{ABSTRACT}

Objectives: Type 2 diabetes mellitus (T2DM) is a metabolic disorder usually characterized by hyperglycemia. Adipose tissue secretes bioactive substances known as adipocytokines including leptin, tumor necrosis factor-alpha (TNF- $\alpha$ ), and adiponectin. These are considered as a bridge connecting obesity and insulin resistance. There is considerable epidemiological evidence to suggest a role of Vitamin D deficiency in the etiology of T2DM. This study was performed to evaluate and compare serum Vitamin D and adipocytokine levels in T2DM patients and healthy controls of Jammu and Kashmir region of India.

Methods: A total of 200 T2DM patients and normal 200 healthy controls were considered for the study. Enzyme-linked immunosorbent assay was used to measure serum leptin and TNF- $\alpha$ levels. The Vitamin D levels were measured by chemiluminescent microparticle immunoassay method. Biochemical parameters were measured by the enzymatic method.

Results: Our results concluded that basic metabolic parameters, TNF- $\alpha$ and leptin levels were significantly higher in cases than controls. The serum Vitamin D levels were found significantly lower among T2DM patients. No correlation of Vitamin D with leptin was observed in cases and controls. However, a positive correlation between leptin and TNF- $\alpha$ was noted in T2DM subjects as well as in controls with statistical significance being higher in females $(r=0.500 ; p=0.001)$ as compared to males $(r=0.298 ; p=0.036)$ in T2DM subjects as well as in controls $(r=0.659 ; p=0.001 ; r=0.621 ; p=001)$.

Conclusion: These results concluded that lowering of Vitamin D levels and upregulation of leptin and TNF- $\alpha$ altogether play an important role in the development of T2DM, and from correlation analysis, it could be predicted that leptin and TNF- $\alpha$ act in a synergistic manner toward the development of T2DM.

Keywords: Type 2 Diabetes Mellitus, Leptin, Tumor necrosis factor- $\alpha$, Vitamin D, Enzyme-linked immunosorbent assay.

(C) 2018 The Authors. Published by Innovare Academic Sciences Pvt Ltd. This is an open access article under the CC BY license (http://creativecommons. org/licenses/by/4. 0/) DOI: http://dx.doi.org/10.22159/ajpcr.2018.v11i10.28097

\section{INTRODUCTION}

Diabetes mellitus is a group of metabolic diseases characterized by hyperglycemia resulting due to insulin insufficiency, diminished insulin action, or both. It is a serious public health problem in developed as well as developing countries [1]. Adipose tissue secretes bioactive peptides which are functionally similar to cytokines and are known as adipocytokines. These include leptin, tumor necrosis factor-alpha (TNF- $\alpha$ ), interleukin- 6 (IL-6), adiponectin, and resistin. These adipocytokines control glucose and fatty acid metabolism [2] and also influence the activity of other tissues [3].

TNF- $\alpha$ is a cytokine which regulates cellular as well as biological processes and has been linked to cancer, lung cardiovascular diseases, and T2DM [4]. It has been documented to alter insulin sensitivity by triggering several key steps in the insulin signaling pathway [5] and effects glucose metabolism [6,7]. It also plays a key role in the pathogenesis of obesity-induced insulin resistance and T2DM $[8,9]$.

Leptin is an adipocyte-secreted hormone/cytokine which regulates energy expenditure, behavior, and glucose metabolism to maintain body fat stores $[10,11]$. It plays a role in reducing insulin secretion from pancreatic $\beta$-cells and inhibits insulin biosynthesis by decreasing preproinsulin mRNA expression in $\beta$-cells. Further, leptin therapy in lipodystrophic patients was shown to improve insulin-stimulated hepatic and peripheral glucose metabolism [12].

Vitamin D is a vital factor for physiological functioning of skeletal as well as non-skeletal tissues where its deficiency can lead to disorders in both the tissues $[13,14]$. It has both direct and indirect effects on insulin secretion, $\beta$-cell function, and insulin resistance $[15,16]$. Several studies have demonstrated a link between Vitamin D deficiency and incidence of T2DM. Recently, Vitamin D receptor gene polymorphism and its association with T2DM has also been demonstrated [17]. Some studies have indicated that lower levels of Vitamin D are associated with higher serum levels of inflammatory biomarkers, such as IL-6, TNF- $\alpha$, and C-reactive protein in healthy [18-21] and obese subjects [22] while others could not confirm these findings [23-26].

\section{METHODS}

The study was carried on 200 T2DM patients (30-70 years) who were diagnosed according to the current ADA diagnostic criteria [1,2] from the Diabetic Outpatient Department and General Medicine Department of Government Medical College and Hospital, Srinagar, India. The same number of age- and sex-matched healthy subjects was also included in the study who served as controls. The study was approved by a Departmental Ethical Committee of Biochemistry, Government Medical College, Srinagar. Patients with evidence of acute or chronic inflammatory or infectious diseases, cancer, persons on insulin, or other medications that could affect glucose metabolism and pregnant or lactating women were excluded from the study.

\section{Anthropometric measurements}

Height $(\mathrm{cm})$ was noted using a measuring tape to the nearest $0.1 \mathrm{~cm}$. Weight $(\mathrm{kg})$ was measured to the nearest $0.1 \mathrm{~kg}$ using a weighing machine, simultaneously. Body mass index (BMI) was calculated as 
Table 1: Basic metabolic parameters, Vitamin D, and adipocytokines measured in cases and controls of the study

\begin{tabular}{llc}
\hline Characteristic & Cases $(\mathbf{n = 2 0 0})$ & Controls (n=200) \\
\hline Fasting plasma glucose $(\mathrm{mg} / \mathrm{dl})$ & $176.49 \pm 43.3$ & $86.33 \pm 12.5$ \\
HbA1c \% & $7.4 \pm 0.18$ & $5.1 \pm 0.05$ \\
Cholesterol (mg/dl) & $179.5 \pm 31.8$ & $165 \pm 41.8$ \\
Triglycerides (mg/dl) & $192.7 \pm 51.2$ & $0.001^{*}$ \\
LDL (mg/dl) & $119.36 \pm 33.29$ & $0.001^{*}$ \\
HDL (mg/dl) & $30.83 \pm 7.67$ & $160 \pm 45.5$ \\
BMI (kg/m) & $26.5 \pm 2.1$ & $32.33 \pm 6.67$ \\
25(OH) D & $19.40 \pm 10$ & $22.5 \pm 4.2$ \\
Leptin & $15.04 \pm 7.8$ & $36.67 \pm 7.5$ \\
TNF- $\alpha$ & $28.77 \pm 14.4$ & $8.17 \pm 4.20$ \\
\hline
\end{tabular}

The data represent mean \pm SD values of variables of T2DM patients and control subjects ( $\mathrm{n}=200) .{ }^{*} \mathrm{p}<0.05,{ }^{* *} \mathrm{p}>0.05$ versus controls (independent $\mathrm{t}$-test). HbA1c: Glycated hemoglobin, LDL: Low-density lipoprotein, HDL: High-density lipoprotein, BMI: Body mass index, TNF- $\alpha$ : Tumor necrosis factor-alpha, SD: Standard deviation, T2DM: Type 2 diabetes mellitus

Table 2: Serum levels of Vitamin D, TNF-alpha, and leptin levels in T2DM male and female patients versus control subjects of the study

\begin{tabular}{|c|c|c|c|c|c|c|}
\hline Adipokine/mediator & Male cases & Female cases & $p$ valve & Male controls & Female controls & $p$ value \\
\hline Vitamin D & $20.27 \pm 10.41$ & $18.52 \pm 10.02$ & $0.36^{* *}$ & $36.84 \pm 7.16$ & $36.50 \pm 7.9$ & $0.48^{* *}$ \\
\hline Leptin & $12.66 \pm 8.60$ & $17.47 \pm 6.30$ & $0.001^{*}$ & $5.69 \pm 4.23$ & $10.63 \pm 2.26$ & $0.001^{*}$ \\
\hline TNF- $\alpha$ & $27.53 \pm 15.10$ & $30.42 \pm 13$ & $0.40^{* *}$ & $11.80 \pm 5.83$ & $13.22 \pm 6.06$ & $0.46^{* *}$ \\
\hline
\end{tabular}

The data represent mean \pm SD values for serum Vitamin D, TNF- $\alpha$, and leptin levels within diabetic cases and control subjects according to gender ( $\mathrm{n}=200) .{ }^{*} \mathrm{p}<0.05$, ${ }^{* *}$ p $>0.05$ (Chi-square test). T2DM: Type 2 diabetes mellitus, TNF- $\alpha$ : Tumor necrosis factor-alpha, SD: Standard deviation

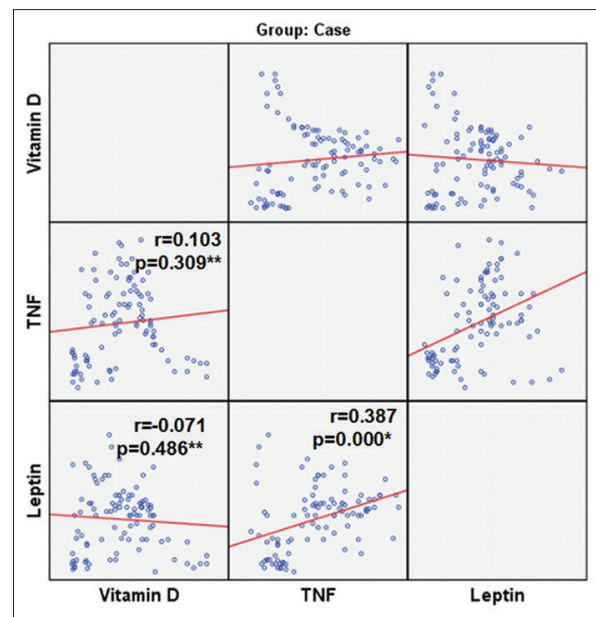

Fig. 1: Correlation between Vitamin D, tumor necrosis factoralpha, and leptin levels in type 2 diabetes mellitus subjects. Each dot on the scatter plot represents one observation/value $(n=200)$. ${ }^{*} \mathbf{p}<0.05,{ }^{* *} \mathbf{p}>0.05$ (Pearson correlation)

the ratio of body weight in $\mathrm{Kg}$ and height in meter square $\left(\mathrm{kg} / \mathrm{m}^{2}\right)$. Participants with a BMI $\geq 30.0 \mathrm{~kg} / \mathrm{m}^{2}$ were considered obese.

\section{Biochemical analysis}

Enzyme-linked immunosorbent assay was used to measure serum leptin (DRG international, USA; EIA-2395) and TNF- $\alpha$ (Diaclone SAS, Besancon Cedex, France) levels as described previously [27]. The serum Vitamin D levels were measured by chemiluminescent microparticle immunoassay method (Abbot Laboratories Illinois, USA). Analysis of serum glucose, glycated hemglobin, cholesterol, low-density lipoprotein, high-density lipoprotein, and triglycerides levels was done by an enzymatic method (Abbot Laboratories Illinois, USA).

Statistical analysis

All data were expressed as a mean \pm standard deviation. Data analysis was performed using SPSS software for Windows version 16. Group means were compared using independent-sample t-test. Correlation analysis was performed for determining the relationship between serum leptin, TNF- $\alpha$, and Vitamin D levels and Pearson correlation

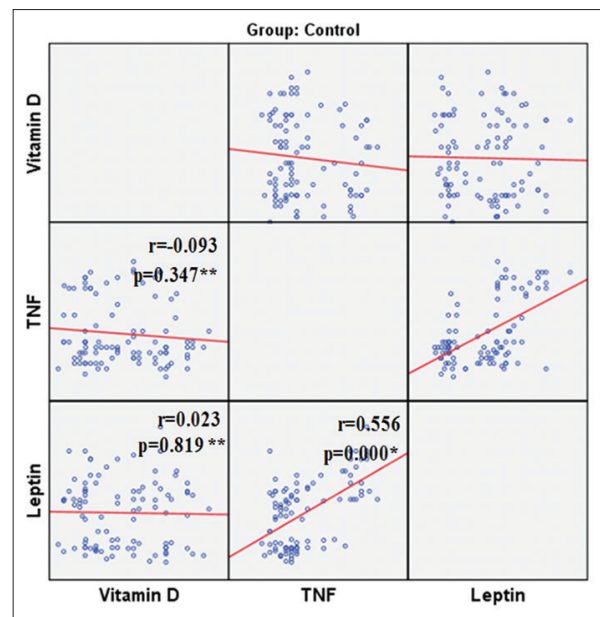

Fig. 2: Correlation between Vitamin D, tumor necrosis factoralpha, and leptin levels in control subjects. Each dot on the scatter plot represents one observation/value $(n=200) .{ }^{*} p<0.05$, $* * \mathbf{p}>0.05$ (Pearson correlation)

coefficient ( $\mathrm{r}$ ) was obtained. For all assessments, a value of $\mathrm{p}<0.05$ was statistically accepted as significant.

\section{RESULTS}

\section{Evaluation of basic metabolic parameters}

Basic metabolic parameters were measured in T2DM patients and control subjects. According to our results, the serum levels of all the metabolic parameters were found to be significantly higher in T2DM patients as compared to control subjects (Table 1).

Evaluation of serum Vitamin D, TNF- $\alpha$, and Leptin levels in T2DM patients and controls

The serum Vitamin D, TNF- $\alpha$, and leptin levels were evaluated in T2DM patients and control subjects. According to our results, T2DM subjects of the study were low in serum Vitamin D levels and high in serum leptin and TNF- $\alpha$ levels as compared to controls ( $p=0.001$; Table 1). Further, the T2DM females of our study were found to have lower Vitamin D levels and higher leptin and TNF- $\alpha$ levels than T2DM males. However, 


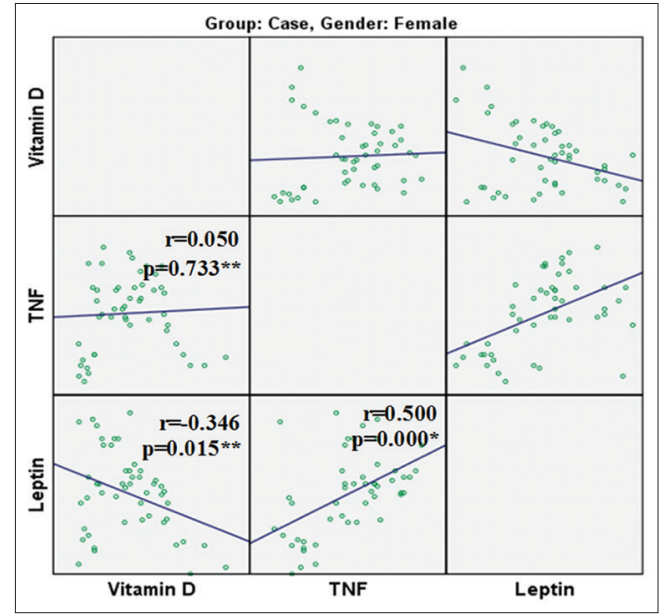

Fig. 3: Correlation between Vitamin D, tumor necrosis factoralpha, and leptin levels in type 2 diabetes mellitus female subjects. Each dot on the scatter plot represents one observation/ value $(\mathrm{n}=100) .{ }^{*} \mathrm{p}<0.05,{ }^{* *} \mathrm{p}>0.05$ (Pearson correlation)

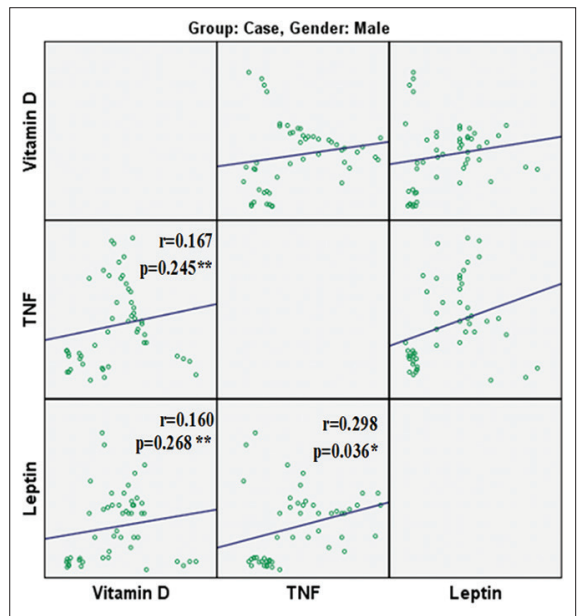

Fig. 4: Correlation between Vitamin D, tumor necrosis factoralpha, and leptin levels in type 2 diabetes mellitus male subjects. Each dot on the scatter plot represents one observation/value $(\mathrm{n}=100) .{ }^{*} \mathrm{p}<0.05,{ }^{* *} \mathrm{p}>0.05$ (Pearson correlation)

significant gender distribution was found for serum leptin levels only $(\mathrm{p}=0.001$; Table 2). The correlation analysis was done between serum Vitamin D, TNF- $\alpha$, and leptin levels and our results concluded that there was a non-significant correlation of Vitamin $\mathrm{D}$ with leptin $(\mathrm{r}=-0.071$; $\mathrm{p}=0.486)$ and TNF- $\alpha(\mathrm{r}=0.103 ; \mathrm{p}=0.309)$ in T2DM patients and controls $(r=0.023 ; p=0.819 ; r=-0.093 ; p=0.347 ;$ Figs. 1 and 2$)$. However, a positive correlation between leptin and TNF- $\alpha(r=0.387 ; p=0.000)$ was found in T2DM subjects as well as in controls ( $\mathrm{r}=0.556$; $\mathrm{p}=0.001$; Figs. 1 and 2$)$ with significance being higher in females ( $r=0.500 ; p=0.001$; Fig. 3 ) as compared to males ( $r=0.298$; $p=0.036$; Fig. 4$)$ in T2DM subjects as well as in controls ( $r=0.659 ; p=0.001$; Fig. 5; r=0.621; $p=0001$; Fig. 6).

\section{DISCUSSION}

T2DM is caused by decreased sensitivity of target tissues to the metabolic effects of insulin and is associated with increased plasma insulin concentration in the body. It accounts for $90 \%$ of all the cases of diabetes, and its complications have become a major cause of morbidity and mortality worldwide. According to a report from International Diabetes Federation, the number of T2DM cases will rise to 552 million by $2030[28,29]$. In T2DM patients lipid peroxidation, lipid levels [30] and antioxidant levels have been found to be altered [31]. There is

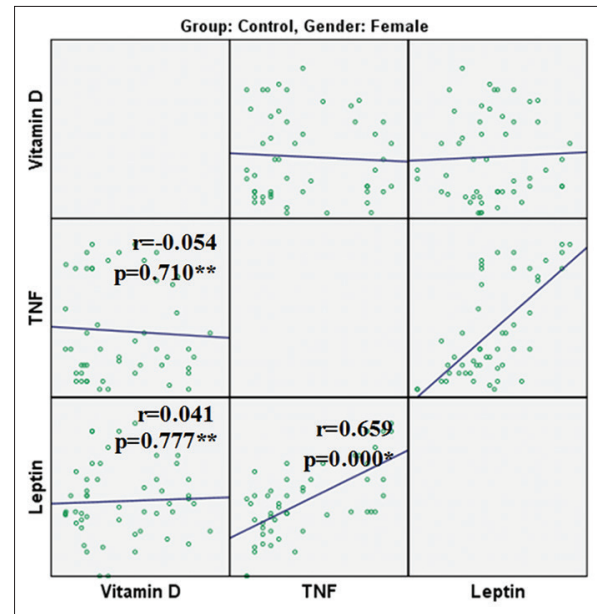

Fig. 5: Correlation between Vitamin D, tumor necrosis factoralpha, and leptin in control female subjects. Each dot on the scatter plot represents one observation/value $(n=100) .{ }^{*} p<0.05$ ${ }^{* *} \mathrm{p}>0.05$ (Pearson correlation)

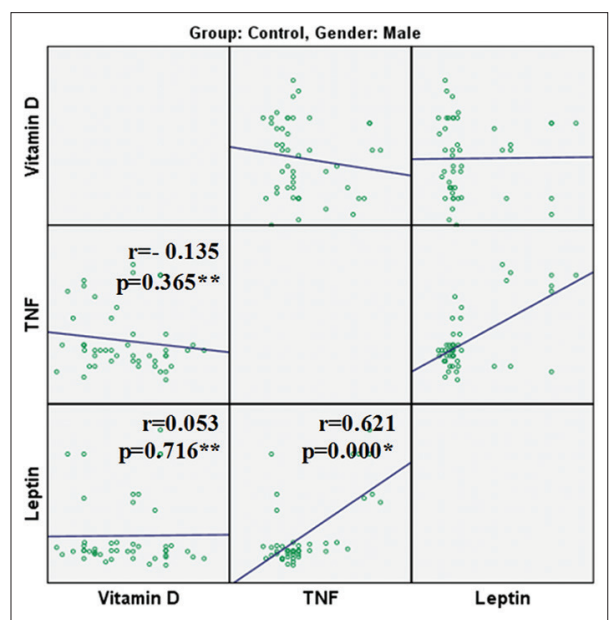

Fig. 6: Correlation between Vitamin D, tumor necrosis factoralpha, and leptin levels in control male subjects. Each dot on the scatter plot represents one observation/value $(n=100) .{ }^{*} \mathbf{p}<0.05$, ${ }^{* *}$ p $>0.05$ (Pearson correlation)

considerable epidemiological evidence to suggest a role of Vitamin D deficiency in the pathogenesis of T2DM and several inflammatory biomarkers have also been found to be associated with $\beta$-cell failure and insulin resistance, both of which are key features of T2DM. Some of these immune mediators, such as TNF- $\alpha$, leptin, and IL- 6 may directly interfere with insulin signaling, causing insulin resistance through several mechanisms [32]. The role of Vitamin D in abnormal glucose metabolism as well as in T2DM has been documented $[29,16]$. Some studies have shown an inverse relationship between Vitamin D and the incidence of T2DM/insulin resistance [30]. Our results followed a pattern of some previous observational studies which demonstrated that the risk of diabetes was negatively associated with increased Vitamin D concentrations [31] as in the present study, serum Vitamin D levels were significantly lower in T2DM patients when compared with healthy subjects. The T2DM females of our study were found to have low serum Vitamin D levels as compared to T2DM males, but the results were statistically insignificant. Therefore, no gender difference for serum Vitamin D levels was seen in our cases, and this gender difference was not seen in controls as well. Hence, in the present study, the high prevalence of hypovitaminosis D in people with T2DM could point to an association between the low Vitamin D status and incidence of T2DM in our community. Some cross-sectional studies indicated 
that low Vitamin D levels are associated with higher serum levels of inflammatory biomarkers such as IL- 6 and TNF- $\alpha$ in healthy [18-21] and obese subjects [22] while others could not confirm these findings [23-27]. Our results are in accordance with Ganji et al. [23], as in our study no significant correlation of Vitamin D levels with inflammatory markers TNF- $\alpha$ or leptin was found in T2DM patients or controls. However, a positive correlation was observed between TNF- $\alpha$ and leptin levels in T2DM patients and controls with correlation being stronger among females in both cases and controls. Due to the presence of leptin receptors in pancreatic $\beta$-cells, there is a strong possibility of leptin modulating insulin secretion which several studies have also inferred. There are mixed data-driven opinions about the association of leptin with T2DM in humans. Several studies did not find an association $[32,33]$ while others demonstrated a significant positive association between serum leptin levels and T2DM in men [34,35] and women [36]. In the present study, serum leptin levels were found significantly higher in T2DM patients than normal healthy controls. T2DM females of the study were found to have higher serum leptin levels than T2DM male subjects which were statistically significant, and this gender difference was seen in controls as well. TNF- $\alpha$ is a pro-inflammatory mediator and is associated with various diseases such as arthritis, sepsis, asthma, and obesity [4,37-39]. TNF- $\alpha$ levels are significantly elevated in subjects with T2DM, because of its role in lipid metabolism or obesity-associated insulin resistance [40]. A study conducted by Miyazaki et al. concluded that TNF- $\alpha$ increases before the onset of T2DM and further increase was not associated with insulin resistance [8]. However, some studies reported that there is no role of TNF- $\alpha$ in the genesis of early stages of insulin resistance [41]. In our study, higher TNF- $\alpha$ levels were found in T2DM patients as compared to controls. The serum levels of TNF- $\alpha$ were higher in T2DM females as compared to T2DM males involved in the study with no statistical significance, which implies that there was no gender difference for serum TNF- $\alpha$ levels in our cases. Similarly, no gender difference was observed in controls as well.

These results concluded that lower Vitamin D levels, and higher leptin, and TNF- $\alpha$ levels play a key role in the development of T2DM and from the correlation analysis it could be predicted that leptin and TNF- $\alpha$ act synergistically toward the development of T2DM.

\section{ACKNOWLEDGMENT}

The technical and non-technical staff of the Department of Biochemistry is highly acknowledged for providing help and support.

\section{AUTHORS' CONTRIBUTION}

Conceptualization: D. I. and M. S.; Methodology: D. I., M.S., R.F., H.I., and K.R.K.; Investigation: D.I., F.R., and Q.J.; Funding acquisition: M.S.

\section{CONFLICTS OF INTEREST}

There were no conflicts of interest among authors.

\section{REFERENCES}

1. Arafat M, Salam A, Arafat O. The association of Type 2 diabetes with obesity and other factors in multinational community. Int J Pharm Pharm Sci 2014;9:257-60.

2. Dhodi JB, Mestry SN, Juvekar AR. Diabetic nephropathy-genesis, prevention and treatment. Int J Pharm Pharm Sci 2014;9:42-7.

3. Nedvidkova J, Smitka K, Kopsky V, Hainer V. Adiponectin, an adipocytederived protein. Physiol Res 2005;54:133-40.

4. Gwozdziewiczova S, Lichnovska R, Yahia RB, Chulp R, Hrebicek J. TNF-alpha in the development of insulin resistance and other disorders in metabolic syndrome. BioMed 2005;149:109-17.

5. Bastard JP, Maachi M, Lagethu C, Kim MJ, Caron M, Vidal H, et al. Recent advances in the relationship between obesity, inflammation and insulin resistance. Euro Cytokine Netw 2006;17:4-12.

6. Zou C, Shao J. Role of adipocytokines in obesity-associated insulin resistance. J Nutr Biochem 2008;19:277-86.

7. Aguirre V, Uchida T, Yenush L, Davis R, White MF. The c-jun NH(2)terminal kinase promotes insulin resistance during association with insulin receptor substrate-1 and phosphorylation of ser(307). J Biol Chem 2000;275:9047-54.

8. Miyazaki Y, Pipek R, Mandarino LJ, DeFronzo RA. Tumor necrosis factor alpha and insulinresistance in obese Type 2 diabetic patients. Int J Obes Relat Metab Disord 2003;27:88-94.

9. Swaroop JJ, Rajarajeswari D, Naidu JN. Association of TNF- $\alpha$ with insulin resistance in Type 2 diabetes mellitus. Indian J Med Res 2012;135:127-30.

10. Kamahora S, Burcelin R, Halaas JL, Friedman JM, Charron MJ. Acute stimulation of glucose metabolism in mice by leptin treatment. Nature 1997;389:374-7

11. Elias CF, Aschkenasi C, Lee C, Kelly J, Ahima RS, Bjorbaek C, et al. Leptin differentially regulates NPY and POMC neurons projecting to the lateral hypothala-micarea. Neuron 1999;23:775-86.

12. Paz-Filho G, Mastronardi C, Wong ML, Licinio J. Leptin therapy, insulin sensitivity, and glucose homeostasis. Indian J Endocr Metab 2012; $16: 549-55$

13. Heaney RP. Functional indices of vitamin D status and ramifications of vitamin D deficiency. Am J Clin Nutr 2004;80:1706-9.

14. Holick MF. High prevalence of vitamin D inadequacy and implications for health. Mayo Clin Proc 2006;81:353-73.

15. Majeed I, Farooq R, Malik R, Majid S. Estimation of lipid peroxidation and lipid profile levels in Type II diabetes mellitus patients of Kashmir valley. Int J Adv Life Sci 2015;40:448-52.

16. Rashid T, Bhat SA, Wani MU, Majid S, Hassan I, Rashid S, et al. The lipid peroxidation and antioxidant status of Type 2 diabetic patients in Kashmir (India). Int J Diab Dev Coun 2015;4:476-81.

17. Malik R, Farooq R, Mehta P, Ishaq S, Din I, Shah P, Majid S. Association of vitamin $\mathrm{D}$ receptor gene polymorphism in patients with Type 2 diabetes in the Kashmir valley. Can J Diab 2017;16:30514-7.

18. Jablonski KL, Chonchol M, Pierce GL, Walker AE, Seals DR. 25-Hydroxy vitamin D deficiency is associated with inflammationlinked vascular endothelial dysfunction in middle-aged and older adults. Hypertension 2011;57:63-9.

19. Peterson CA, Heffernan ME. Serum tumor necrosis factor-alpha concentrations are negatively correlated with serum vitamin D concentrations in healthy women. J Inflam 2008;5:5-10.

20. Ngo DT, Sverdlov AL, McNeil JJ, Horowitz JD. Does vitamin D modulate asymmetric dimethylarginine and $\mathrm{C}$-reactive protein concentrations? Am J Med 2010;123:335-41.

21. Dobnig H, Pilz S, Scharnagl H, Renner W, Seelhorst U, Wellnitz B, et al. Independent association of low serum 25-hydroxy vitamin D and 1, 25-dihydroxy vitamin $\mathrm{D}$ levels with all-cause and cardiovascular mortality. Arch Intern Med 2008;168:1340-9.

22. Bellia A, Garcovich CD, Adam M, Lombardo M, TesauroM, Donadel G, et al. Serum 25-hydroxyvitamin D levels are inversely associated with systemic inflammation in severe obese subjects. Intern Emerg Med 2011; 8: 33-40

23. Ganji V, Zhang X, Shaikh N, Tangpricha V. Serum 25-hydroxyvitamin D concentrations are associated with prevalence of metabolic syndrome and various cardiometabolic risk factors in US children and adolescents based on assay-adjusted serum 25-hydroxyvitamin D data from NHANES 2001-2006. Am J Clin Nutr 2011;94:225-33.

24. Hyppoenen E, Berry D, Cortina-Borja M, Power C. 25-Hydroxyvitamin $\mathrm{D}$ and pre-clinical alterations in inflammatory and hemostatic markers: A cross sectional analysis in the 1958. PLoS One 2010;5:e10801.

25. Jorde R, Haug E, Figenschau Y, Hansen JB. Serum levels of vitamin $\mathrm{D}$ and haemostatic factors in healthy subjects: The Tromso study. Acta Haemat 2007;117:91-7.

26. Vilarrasa N, Vendrell J, Maravall J, Elio I, Solano E, San Jose P, et al. Is plasma vitamin $\mathrm{D}$ related to adipokines, inflammatory cytokines and insulin resistance in both a healthy and morbidly obese population? Endocrine 2010;38:235-42.

27. Rayees S, Mabalirajan U, Bhat WW, Rasool S, Rather RA, Panda L, et al. Therapeutic effects of R8, a semi-synthetic analogue of Vasicine, on murine model of allergic airway inflammation via STAT6 inhibition. Int Immunopharmacol 2015;26:246-56

28. Olokoba AB, Obateru OA, Olokoba LB. Type 2 diabetes mellitus: A review of current trends. Oman Med J 2012;4:269-73.

29. Palomer X, Gonzalez-Clemente JM, Blanco-Vaca F, Mauricio D. Role of vitamin D in the pathogenesis of Type 2 diabetes mellitus. Diabetes Obes Metab 2008;10:185-97.

30. Scragg R, Holdaway I, Singh V, Metcalf P, Baker J, Dryson E, et al. Serum 25-hydroxyvitamin D3 levels decreased in impaired glucose tolerance and diabetes mellitus. Diabetes Res Clin Pract 1995;27:181-8.

31. Pittas A, Dawson-Hughes B. Vitamin D and diabetes. J Sterol Biochem Mol 2010;121:425-9. 
32. Haffner SM, Stern MP, Miettinen H, Wei M, Gingerich RL. Leptin concentrations in diabetic and nondiabetic Mexican-Americans. Diabetes 1996;45:822-4.

33. Maahs DM, Hamman RF, D'Agostino R Jr., Dolan LM, Imperatore G, Lawrence JM, et al. The association between adiponectin/leptin ratio and diabetes type: The search for Diabetes in youth study. J Pediatr 2009; $155: 133-5$.

34. Wannamethee SG, Tchernova J, Whincup P. Plasma leptin: Associations with metabolic, inflammatory and haemostatic risk factors for cardiovascular disease. Atherosclerosis 2007;191:418-26.

35. Welsh P, Murray HM, Buckley BM, de Craen AJ, Ford I, Jukema JW, et al. Leptin predicts diabetes but not cardiovascular disease: Results from a large prospective study in an elderly population. Diabetes Care 2009;32:308-10.

36. Sun Q, van Dam RM, Meigs JB, Franco OH, Mantzoros CS, Hu FB, et al. Leptin and soluble leptin receptor levels in plasma and risk of Type 2 diabetes in U.S. Women: A prospective study. Diabetes 2010;59:611-8.

37. Rayees S, Malik F, Bukhari SI, Singh G. Linking GATA-3 and interleukin-13: Implications in asthma. Inflamm Res 2014;4:255-65.

38. Rayees S, Kumar A, Rasool S, Kaiser P, Satti NK, Sangwan PL, et al. Ethanolic extract of Alternanthera sessilis (AS-1) inhibits IgE-mediated allergic response in RBL-2H3 cells. Immunol Invest 2013;6:470-80.

39. Rayees S, Johri RK, Singh G, Tikoo MK, Singh SS, Sharma SC, Rai PK, et al. Sitopaladi, a poly-herbal formulation inhibits IgE mediated allergic reactions. Spatula DD 2012;2:75-82.

40. Moller DE. Potential role of TNF-alpha in the pathogenesis of insulin resistance and Type 2 diabetes. Trends Endocrin Metab 2000; 11: 212-7.

41. Bluher M, Kratzsch J, Paschke R. Plasma levels of tumor necrosis factor-alpha, angiotensin II, growth harmone, and IGF-1 are not elevated in insulin-resistant obese individuals with impaired glucose tolerance. Diab Care 2001;24:328-34. 